\title{
Metallomics
}

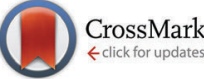

Cite this: Metallomics, 2014, 6,1639

Received 21st March 2014, Accepted 4th July 2014

DOI: $10.1039 / c 4 m t 00085 d$

www.rsc.org/metallomics

\section{Quantification of pharmaceutical peptides using selenium as an elemental detection label}

\author{
Laura Hyrup Møller, ${ }^{a}$ Charlotte Gabel-Jensen, ${ }^{a}$ Henrik Franzyk, ${ }^{b}$ \\ Jesper Søborg Bahnsen, ${ }^{a}$ Stefan Stürup ${ }^{a}$ and Bente Gammelgaard ${ }^{\star a}$
}

\begin{abstract}
The aim of the present work was to demonstrate how selenium labelling of a synthetic cell-penetrating peptide may be employed in evaluation of stability and quantitative estimation of cellular uptake by inductively coupled plasma mass spectrometry (ICP-MS). Two analogues of the cell-penetrating peptide, penetratin, were synthesized, one with selenomethionine (SeMet) added at the N-terminal of the peptide $\left(\mathrm{N}-\mathrm{PenM} \mathrm{M}^{\mathrm{Se}}\right.$ ) and the other with the internal methionine (Met) replaced with SeMet (i-PenM ${ }^{\mathrm{Se}}$ ). The purity of the synthesized peptides was $92 \%$ for $\mathrm{N}-\mathrm{PenM} \mathrm{M}^{\mathrm{Se}}$ and $89 \%$ for $\mathrm{i}-\mathrm{Pen} \mathrm{M}^{\mathrm{Se}}$ as determined by liquid chromatography (LC)-ICP-MS. The selenium-labelled peptides were investigated by cell uptake studies in HeLa WT cells. The stability of the peptides was monitored in water, cell medium and during cell uptake studies. Total uptake of selenium was quantified by flow injection (FI)-ICP-MS. Speciation analysis of cell samples by LC-ICP-MS showed mainly uptake of the intact peptides, while the amount of intact peptides in cell lysates was semi-quantitatively determined. The selenium-containing penetratin analogues were to some extent degraded in pure cell medium, while an extensive degradation was observed during cell uptake studies. The major degradation products were determined by LC-electrospray ionization mass spectrometry (ESI-MS). The labelling method in combination with FI-ICP-MS, LC-ICP-MS and LC-ESI-MS techniques provided detailed information on the fate of penetratin in cellular uptake studies. Most pharmaceutical peptides, including penetratin, are synthetic analogues of endogenous peptides, and incorporation of selenium may improve the critical assessment of the native drug or drug delivery candidate early in the drug development process.
\end{abstract}

\section{Introduction}

Peptides are involved in a large variety of physiological processes and cell functions and several peptide drugs have already been successfully applied for treatment of, for instance, certain cancer forms and type 2 diabetes. The interest in exploiting peptides as drug substances has increased rapidly during the last few decades. Although the annual sale of peptide drugs is only a few percent of the global drug market, it is increasing twice as fast as the market for classical small molecules. ${ }^{1}$ In the period of 2000-2012, marketing approvals for 19 peptides were obtained in USA, six of these were approved in 2012. A large number of peptides are in the pipeline and several have reached the Phase II and Phase III clinical trials. The therapeutic areas of the Phase I and Phase II candidates are mainly metabolic diseases and oncology, while the major indications for the Phase III candidates are oncology and infectious diseases. ${ }^{2}$

\footnotetext{
${ }^{a}$ University of Copenhagen, Department of Pharmacy, Denmark.

E-mail: bente.gammelgaard@sund.ku.dk

${ }^{b}$ University of Copenhagen, Department of Drug Design and Pharmacology, Denmark
}

Peptides often offer high efficacy, selectivity and specificity as drug candidates, and as their degradation products are amino acids and smaller peptides they are associated with low risk of systemic toxicity. However, peptides exhibit low oral bioavailability owing to their high propensity to enzymatic degradation in the gastrointestinal tract combined with a low intestinal barrier passage. ${ }^{3}$ Development of drug delivery systems is therefore an integrated research area for improving the bioavailability of potential drug candidates. ${ }^{4}$ Drug delivery by nanoparticles and development of cell penetrating peptides (CPPs) are examples of such efforts. ${ }^{5}$

In order to monitor the stability, pharmacokinetics and metabolism of pharmaceutical peptides, development of sensitive quantitative analytical methods for peptides is of great importance. A challenge in monitoring the fate of peptides in complex biological systems is to obtain adequate selectivity and sensitivity.

Pharmaceutical peptides comprising 5-50 amino acids are predominantly produced by solid-phase peptide synthesis (SPPS). This opens up the possibility of introducing a label for detection and thereby enhance analytical selectivity. ${ }^{3,6}$

Quantification of peptides has traditionally been performed by liquid chromatography (LC) with detection by UV absorption ${ }^{7-9}$ or 
fluorescence emission spectroscopy. ${ }^{10,11}$ However, UV detection has limited sensitivity and specificity, whereas fluorescence detection demands either inherent fluorescent properties of the biomolecule or labelling with a fluorophore. With development of high-resolution mass spectrometry (MS), this technique is increasingly applied in quantitative peptide analysis. ${ }^{12}$ Recently, inductively coupled plasma mass spectrometry (ICP-MS) was proposed as a complementary method to molecular MS for quantification of peptides. The advantages of ICP-MS are low detection limits, a wide dynamic range and in principle matrixindependent sensitivity of different species of the heteroelements. This opens up the opportunity for quantification by using a single inorganic element standard in contrast to species-specific standards needed for molecular MS. ${ }^{13,14}$ However, detection of $\mathrm{C}$, O and $\mathrm{N}$, the main constituents of biomolecules, is not possible by ICP-MS due to use of an open plasma causing interferences from the air. Fortunately, a wide range of proteins naturally contain ICP-MS detectable heteroelements, e.g. S in methionine (Met) and cysteine (Cys), Se in selenoproteins, $\mathrm{P}$ in phosphoproteins or I in thyroid hormones. The occurrence of selenoproteins, phosphoproteins and thyroid hormones is moderate in number, and sulfur analysis is restricted due to low ionization efficiency and spectral interferences in ICP-MS resulting in lower sensitivity. ${ }^{13}$ In order to enhance sensitivity, several different ICP-MS sensitive labels have been suggested, and these possibilities have been reviewed by Prange and Pröfrock, ${ }^{13}$ Kretschy et al. ${ }^{15}$ and Wang et $a{ }^{16}$ Two different approaches are generally pursued when labelling biomolecules: pre-labelling and post-labelling. In proteomics, post-labelling is often applied via labelled antibodies targeting the biomolecule ${ }^{17}$ or through direct conjugation with derivatizing agents. ${ }^{18}$ In the pre-labelling approach the biomolecule is labelled prior to its introduction into a biological system and hence it remains detectable throughout the experiment. This approach is mainly used when analyzing smaller biomolecules as in the present work.

The ideal peptide labelling probe should enhance the sensitivity and neither affect the functionality of the peptide nor the analytical properties. Incorporation of the label should be well controlled, easy to handle and stoichiometrically unequivocal. All these requirements are not readily achieved. Only a few studies on elemental labelling for ICP-MS analysis of therapeutic peptides have been reported, mainly involving chelating agents. ${ }^{15,19}$ Chelating agents typically consist of a lanthanide/metal chelating moiety linked to a reactive group targeting a specific functional group in the peptide, e.g. primary amines or thiols in cysteines. Liu et al. addressed the importance of monitoring the labelling procedure ensuring 1:1 labelling stoichiometry. They reported that a mixture of labelled bradykinin with peptide : label ratios of $1: 1$ and $2: 1$ was obtained by use of a reactive moiety containing two reactive groups, diethylenetriamine- $N, N, N^{\prime}, N^{\prime \prime}, N^{\prime \prime}$-pentaacetic dianhydride (DTPAA), selective for conjugation to primary amines. ${ }^{20}$ In addition, labelling with DTPAA may result in diastereomeric mixtures of the labelled peptides challenging the subsequent analysis. ${ }^{21}$ Labelling reactions have been optimized to avoid formation of diastereomers, ${ }^{22}$ however, consideration for the possible presence of multiple labelling sites in the peptide is important. Furthermore, subsequent separation of free label and labelled peptide is necessary during pre-labelling. ${ }^{23} \mathrm{~A}$ few studies have demonstrated labelling with indium by use of DOTA $(1,4,7,10$ tetraazacyclododecane- $N, N^{\prime}, N^{\prime \prime}, N^{\prime \prime \prime}$-tetraacetic acid), introducing the label during peptide synthesis, ensuring 1:1 labelling stoichiometry. ${ }^{24,25}$ The advantage of lanthanide or metal chelating agents is considerably enhanced sensitivity of the biomolecule during ICP-MS analysis, however, the relatively large chelating moiety will affect the peptide structure and thereby the physico-chemical properties and potentially cell uptake, which is undesirable in studies employing pre-labelled peptides.

In the present study, we introduce selenium as a label in peptides by substitution of Met with the naturally occurring selenium analogue, selenomethionine (SeMet) during peptide synthesis. Selenium labelling constitutes an attractive noninterfering method of probing biological systems, while ensuring unambiguous labelling stoichiometry. Sulfur and selenium belong to the group of chalcogens in the periodic table and thus display similar chemical characteristics. ${ }^{26}$ Due to these comparable properties, it may be assumed that peptides incorporating SeMet instead of Met will display similar biological effects. This is corroborated by the fact that SeMet may randomly be exchanged with Met in humans as the body cannot distinguish between Met and SeMet. ${ }^{27}$ Synthetic selenopeptides have been examined for a wide range of applications, for instance, synthetic exchange of disulfide bridges in peptides with diselenide or selenosulfo bridges has been reported for a wide range of bioactive peptides in order to improve stability. ${ }^{28}$ Lang et al. have proposed introduction of SeMet as an improved target for thiophilic labelling with iodoacetamide reagents as compared to Met, since selenium is more nucleophilic as compared to sulfur. ${ }^{29}$ To the best of our knowledge, selenium has not previously been introduced as a synthetic label for detection in quantitative analysis.

The aim of the present work was to explore whether selenium labelling of a synthetic cell-penetrating peptide may be employed in evaluation of stability and quantitative cell uptake by ICP-MS. Labelling with SeMet was demonstrated for the cellpenetrating peptide (CPP) penetratin, consisting of 16 amino acids including a Met residue, RQIKIWFQNRRMKWKK. The peptide was originally derived from the Drosophila antennapedia transcription protein, and this 16-residue sequence was shown to be one of the minimal peptide sequences maintaining cell-penetrating properties. ${ }^{30}$ In addition, penetratin is able to deliver covalently conjugated drug cargoes through cell membranes, thus offering potential opportunities in the development of new drug delivery systems. ${ }^{5,31}$ Two seleniumcontaining analogues were investigated, one with SeMet added at the N-terminal of the peptide $\left(\mathrm{N}-\mathrm{PenM}^{\mathrm{Se}}\right)$ and the other with the internal Met replaced with SeMet $\left(\mathrm{i}-\mathrm{PenM}^{\mathrm{Se}}\right)$.

\section{Experimental}

\section{Instrumentation}

Inductively coupled plasma mass spectrometry. All ICP-MS measurements were performed on a PE Sciex ELAN 6000 
Inductively Coupled Plasma Mass Spectrometer (ICP-MS) (Perkin Elmer, Norwalk, CT, USA) equipped with a MicroMist glass nebulizer (AHF, Lab Support Hillerød, Denmark) and a PC3 cyclonic spray chamber (Elemental Scientific Inc., Omaha. NE, USA) operated at $4{ }^{\circ} \mathrm{C}$. The sampler and skimmer cones were made of platinum. The nebulizer gas flow, lens voltage and ICP RF power were optimized daily using a solution of $100 \mu \mathrm{g}$ Se per liter in mobile phase. The data acquisition settings for flow injection - dwell time, $50 \mathrm{~ms}$; sweeps per reading, 1; and readings per replicate - were varied according to the number of samples. For speciation analysis, a desolvation system (Aridus II, CETAC Technologies) with a $200 \mu \mathrm{L} \mathrm{min}{ }^{-1}$ nebulizer was applied in order to remove the organic solvent from the eluent prior to introduction into the ICP-MS. Desolvation system settings: spray chamber temperature $110{ }^{\circ} \mathrm{C}$; desolvator temperature $160{ }^{\circ} \mathrm{C}$; sweep gas flow $7 \mathrm{~mL} \mathrm{~min}{ }^{-1}$; and nitrogen gas flow $6 \mathrm{~mL} \mathrm{~min}^{-1}$. ICP-MS nebulizer gas flow was $0.9 \mathrm{~mL} \mathrm{~min}^{-1}$. Lens voltage and ICP RF power were optimized regularly through the desolvation system on a solution of i-PenM $\mathrm{M}^{\text {Se }}$ containing $10 \mu \mathrm{g}$ of Se per liter in mobile phase (50\% methanol). Data acquisition settings for speciation analysis: dwell time $200 \mathrm{~ms}$; sweeps per reading 1; and readings per replicate $1325 .{ }^{77} \mathrm{Se}^{+},{ }^{78} \mathrm{Se}^{+}$and ${ }^{82} \mathrm{Se}^{+}$isotopes were monitored; ${ }^{82} \mathrm{Se}^{+}$was used for quantitative determination.

Molecular mass spectrometry. All MS measurements were performed on a Q Exactive Orbitrap mass spectrometer (Thermo Scientific) with $250{ }^{\circ} \mathrm{C}$ heated electrospray ionization. The sheath gas was set to 30 arbitrary units; auxiliary gas to 10 arbitrary units; capillary temperature to $350{ }^{\circ} \mathrm{C}$; and spray voltage to $3300 \mathrm{~V}$. The MS was run in full scan positive mode. The scan range was $300-3000 \mathrm{~m} / \mathrm{z}$, with a lock mass of $445.120 \mathrm{~m} / \mathrm{z}$, and the mass accuracy was below $1 \mathrm{ppm}$. The instrument was mass calibrated prior to analysis.

\section{Reagents}

Rink amide resin, coupling reagents and amino acid building blocks for solid-phase peptide synthesis as well as supplementary solvents and chemicals were acquired from Iris Biotech (Marktredwitz, Germany). L-Selenomethionine (SeMet) was obtained from TCI Europe. For mobile phases, glacial acetic acid, trifluoroacetic acid (TFA) and methanol were obtained from BDH Prolabo (France).

\section{Procedures}

Peptide synthesis and labelling. All peptides were synthesized by Fmoc-based solid-phase peptide synthesis (SPPS) using a microwave-assisted automated CEM Liberty synthesizer (CEM, Matthews, NC, US). H-SeMet-OH was N-protected with $\mathrm{N}$-(9-fluorenylmethoxycarbonyloxy)succinimide (Fmoc-OSU) to give Fmoc-SeMet-OH; ${ }^{1} \mathrm{H}$ NMR $(600 \mathrm{MHz}$, dimethylsulfoxide$\left.\mathrm{d}_{6}\right): \delta 12.66(1 \mathrm{H},-\mathrm{COOH}), 7.89(2 \mathrm{H}, \mathrm{d}, J=7.5 \mathrm{~Hz}, \mathrm{Fmoc} \mathrm{Ar}-\mathrm{H})$, $7.72(1 \mathrm{H}, \mathrm{d}, J=7.5 \mathrm{~Hz}$, Fmoc Ar-H), $7.72(1 \mathrm{H}, \mathrm{d}, J=7.5 \mathrm{~Hz}$, Fmoc $\mathrm{Ar}-\mathrm{H}), 7.67(1 \mathrm{H}, \mathrm{d}, J=8.2 \mathrm{~Hz},-\mathrm{OCONH}-), 7.42(2 \mathrm{H}, \mathrm{t}, J=7.5 \mathrm{~Hz}$, Fmoc Ar-H), 7.33 (2H, br t, $J=7.5 \mathrm{~Hz}$, Fmoc Ar-H), 4.33-4.27 $\left(2 \mathrm{H}, \mathrm{m}, \mathrm{Fmoc}-\mathrm{CH}_{2}-\right), 4.23(1 \mathrm{H}, \mathrm{br} \mathrm{t}, J=7.1 \mathrm{~Hz}, \mathrm{Fmoc}-\mathrm{CH}-)$, $4.09(1 \mathrm{H}, \mathrm{m}, \mathrm{H}-\alpha), 2.58\left(1 \mathrm{H}, \mathrm{ddd}, J=12.4,8.7\right.$ and $\left.5.1 \mathrm{~Hz}, \mathrm{H}_{\mathrm{A}^{-}}-\beta\right)$, $2.51\left(1 \mathrm{H}\right.$, obsc. by solvent peak, $\left.\mathrm{H}_{\mathrm{B}}-\beta\right), 2.04-1.93(2 \mathrm{H}, \mathrm{m}, \mathrm{H}-\gamma)$, $1.94\left(3 \mathrm{H}, \mathrm{s},-\mathrm{CH}_{3}\right) .{ }^{13} \mathrm{C}$ NMR (150 MHz; dimethylsulfoxide- $\left.\mathrm{d}_{6}\right)$ : $\delta$ 173.58, 156.18, 143.84, 143.77, 140.73, 140.72, 127.64 (2C), 127.06 (2C), 125.26, 125.24, 120.12, 120.10, 65.56, 53.61, 46.67, $31.39,20.96,3.46$. N-terminal labelling of penetratin with SeMet was performed using Fmoc-SeMet-OH (2.5 eq.), benzotriazol-1-yloxytripyrrolidinophosphonium hexafluorophosphate (РyBOP; 2.5 eq.) and $N, N$-diisopropylethylamine (DIPEA; 5 eq.) in DMF at room temperature for $3 \mathrm{~h}$ in a teflon reactor $(10 \mathrm{~mL})$ equipped with a polypropylene filter. Incorporation of SeMet into i-PenM ${ }^{\text {Se }}$ was performed during automated peptide synthesis. Peptides were purified by preparative HPLC (Luna C18(2) column, $5 \mu \mathrm{m}$, $250 \times 21 \mathrm{~mm}$; Phenomenex) with UV detection at $280 \mathrm{~nm}$. A linear gradient of $0-35 \%$ eluent $\mathrm{B}\left(\mathrm{H}_{2} \mathrm{O}: \mathrm{MeCN}\right.$ 95:5 with $0.1 \%$ TFA) in eluent $\mathrm{A}\left(\mathrm{H}_{2} \mathrm{O}\right.$ : MeCN 5 : 95 with $0.1 \%$ TFA) within $20 \mathrm{~min}$ was applied. The flow rate was $20 \mathrm{~mL} \mathrm{~min}^{-1}$.

\section{Cell culture}

The human cervical cancer cell line HeLa WT was obtained from American Type Culture Collection (ATCC) and maintained in Eagle's minimal essential medium (EMEM) supplemented with penicillin $\left(100 \mathrm{U} \mathrm{mL}^{-1}\right)$, streptomycin $\left(100 \mu \mathrm{g} \mathrm{mL} \mathrm{mL}^{-1}\right)$, L-glutamine (2 $\mathrm{mM})$, non-essential amino acids $(0.1 \mathrm{mM})$, sodium pyruvate $(1 \mathrm{mM})$ and $10 \%$ fetal bovine albumin (FBS) (Fischer Scientific, Slangerup, Denmark). The cells were grown in an atmosphere of $5 \% \mathrm{CO}_{2}$ at $37{ }^{\circ} \mathrm{C}$ to $80 \%$ confluence and then sub-cultured at a ratio of approximately $1: 5$ twice a week. Cells, $7.6 \times 10^{4}$, were seeded onto 24-well plates (Fischer Scientific, Slangerup, Denmark).

\section{Cell uptake studies}

Experiments were performed 22-24 h after seeding of the HeLa WT cells; by then, a sub-confluent monolayer (80-90\% confluence) was achieved. Peptide solutions $(10 \mu \mathrm{M})$ in Hanks Balanced Salt Solution (HBSS; Gibco, Paisley, UK) supplemented with $10 \mathrm{mM}$ 4-(2-hydroxyethyl)-1-piperazine ethanesulfonic acid (HEPES, SigmaUltra) were prepared immediately prior to use in cell uptake studies from aqueous $200 \mu \mathrm{M}$ peptide stock solutions prepared within 2 weeks from the uptake experiment and stored at $4{ }^{\circ} \mathrm{C}$. The uptake study was initiated by washing the cells once with $37^{\circ} \mathrm{C}$ phosphate buffered saline (PBS, Sigma), and subsequent addition of $400 \mu \mathrm{L}$ of peptide solution. The cells were then incubated with peptide solution for $2 \mathrm{~h}$ on an orbital shaker (90 rpm) at $37^{\circ} \mathrm{C}$. After exactly $2 \mathrm{~h}$, medium was collected and immediately acidified with acetic acid to a final concentration of $2 \%$. The cell uptake was terminated by washing the cells four times with ice-cold PBS, and then the cells were lysed by addition of $100 \mu \mathrm{L}$ of $0.1 \%$ Triton-X 100 in $2 \%$ acetic acid and kept on ice for $10 \mathrm{~min}$. The lysis mixture was transferred into low-binding Eppendorf tubes (Alpha Laboratories), centrifuged at $25000 \mathrm{~g}$ and the supernatant was collected for analysis. All samples were stored at $-18{ }^{\circ} \mathrm{C}$ until analysis.

\section{Determination of total selenium by flow injection analysis}

Total selenium was determined by flow injection analysis (FI) using an aqueous carrier fluid of $0.02 \%$ trifluoroacetic acid (TFA), 
$0.1 \%$ acetic acid and 5\% methanol. The flow rate was

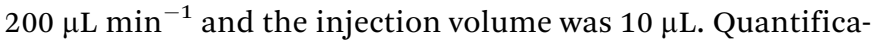
tion was performed by single standard calibration based on peak areas of a $50 \mu \mathrm{g} \mathrm{L^{-1 }}$ solution of certified selenium element standard (Se concentration of $1010 \mathrm{mg} \mathrm{L}^{-1}$, PlasmaCAL, SCP Science, Canada).

\section{LC-ICP-MS (Aridus)}

For LC-ICP-MS analysis, an Agilent 1100 series HPLC system equipped with a degasser, a quaternary pump, an autosampler and a column oven was used. The column was an Aeris PEPTIDE XB-C18, $3.6 \mu \mathrm{m}, 100 \times 2.1 \mathrm{~mm}$ ID column protected by a C18-Peptide SecurityGuard ULTRA cartridge (Phenomenex, SupWare, Denmark). A linear gradient of $20-80 \%$ methanol, (with $0.1 \%$ acetic acid and $0.05 \%$ TFA added) within 10 min was applied with a flow rate of $200 \mu \mathrm{L} \mathrm{min}{ }^{-1}$, a column temperature of $60{ }^{\circ} \mathrm{C}$, and an injection volume of $5 \mu \mathrm{L}$. Semiquantitative peptide uptake was determined by use of a single standard solution of $2.4 \mu \mathrm{M}$ i-PenM ${ }^{\text {Se }}$ standardized for total selenium content with a certified selenium element standard (PlasmaCAL, SCP Science, Canada), concentration of $1010 \mathrm{mg} \mathrm{L}^{-1}$ of Se.

\section{LC-ESI-MS}

UHPLC-ESI-MS analysis was performed on a Dionex Ultimate 3000 UHPLC (Thermo Scientific) equipped with a degasser, a quaternary pump, an autosampler, a thermostated column compartment and a diode array detector (DAD) and hyphenated to a Q Exactive Orbitrap mass spectrometer. The column and mobile phase described for LC-ICP-MS were applied for this system as well. However, the linear gradient was shortened to $20-62 \%$ methanol (with $0.1 \%$ acetic acid and $0.05 \%$ TFA added) within $7 \mathrm{~min}$ to reduce time of analysis. MS data were collected between 2.5 and $10 \mathrm{~min}$.

\section{Results and discussion}

\section{Peptide synthesis}

The obvious approach for labelling a peptide with selenium would be to substitute a sulfur-containing amino acid with its selenium analogue, i.e. selenocysteine (SeCys) or selenomethionine (SeMet). Cysteine is usually avoided in peptide synthesis because of high redox potentials and thereby low stability. Selenoamino acids are generally more readily oxidized during synthesis and purification compared to the sulfur analogues; with the reactivity of SeCys exceeding that of SeMet. ${ }^{26}$ Thus, SeMet was chosen for selenium labelling in the present study. Exchange of Met in penetratin with other neutral amino acids, leucine (Leu) or alanine (Ala), has been reported in the literature without a significant change in cell uptake in HeLa WT cells and HaCAT cells respectively. ${ }^{32,33}$ Hence, exchange of Met appears to be a convenient labelling site in penetratin.

Synthesis was carried out by employing microwave (MW)assisted automated solid-phase peptide synthesis (SPPS). In order to test whether it was possible to introduce SeMet into the peptide sequence with a reasonable yield and purity, a penetratin analogue with SeMet added at the $\mathrm{N}$-terminal $\left(\mathrm{N}-\mathrm{PenM} \mathrm{M}^{\mathrm{Se}}\right)$ was initially
Table 1 Synthetic Se-containing penetratin analogues (i-PenM ${ }^{\text {Se. internal }}$ SeMet incorporated. N-PenM ${ }^{\text {Se: }}$ SeMet added at the N-terminal)

\begin{tabular}{|c|c|c|c|}
\hline Abbreviation & Sequence & $M_{\text {monoisotopic }}$ & $M_{\text {average }}$ \\
\hline $\begin{array}{l}\text { i-PenM } \\
\text { Se } \\
\text { Nenen }\end{array}$ & RQIKIWFQNRR $\left(\mathrm{M}^{\mathrm{Se}}\right) \mathrm{KWKK} \mathrm{NH}_{2}$ & 2292.250 & 2292.638 \\
\hline
\end{tabular}

synthesized (sequence shown in Table 1). As a standard $\mathrm{C} \rightarrow \mathrm{N}$ SPPS strategy was applied, the peptide was conveniently modified by introduction of SeMet at the $\mathrm{N}$-terminal subsequently to MW-assisted automatic synthesis. Thereby, minimum exposure of SeMet to reagents was ensured, and thus the risk of SeMet oxidation was minimized. Also, it was intended to avoid MW irradiation in this initial labelling experiment as it might not be compatible with SeMet. Furthermore, N-terminal labelling of penetratin has been widely used for introduction of fluorescent dyes and covalent attachment of drug cargoes. ${ }^{34-36}$ Synthesis and purification of $\mathrm{N}-\mathrm{PenM}^{\mathrm{Se}}$ was accomplished, and purity of the resulting selenopeptide was determined by LC-ICP-MS to be $92 \%$ as illustrated in Fig. 1. It appears from the figure that an impurity, eluting immediately before the desired peptide, was present. By LC-ESI-MS, a signal was observed at $\mathrm{m} / \mathrm{z}$ 606.831, corresponding to the $[\mathrm{M}+4 \mathrm{H}]^{4+}$ ion of a peptide with mass 2423.293 confirming $\mathrm{N}-\mathrm{PenM}^{\mathrm{Se}}(2423.290 \mathrm{Da})$ as the primary product $(\Delta M \leq 1 \mathrm{ppm})$. A signal from the impurity was seen at $m / z 606.326$ corresponding
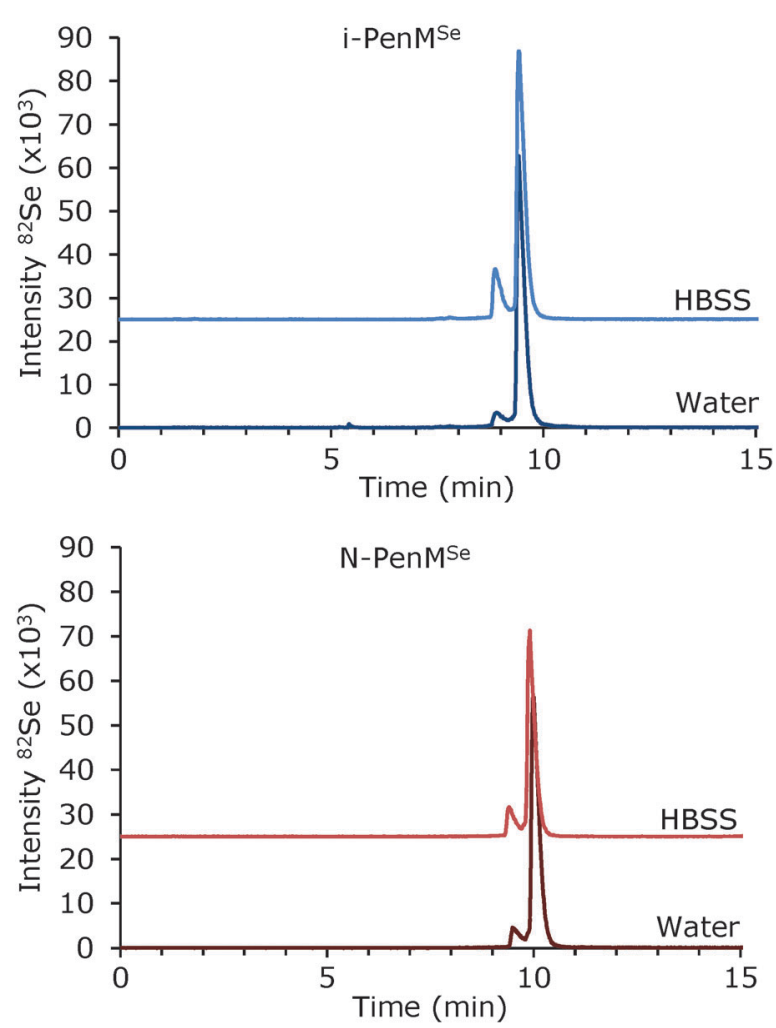

Fig. 1 LC-ICP-MS chromatograms of $\mathrm{i}-\mathrm{PenM}^{\mathrm{Se}}$ and $\mathrm{N}-\mathrm{PenM} \mathrm{M}^{\mathrm{Se}}$ in water and HBSS medium. The amount of the intact peptide determined as the percentage of total selenium in the chromatogram: i-PenM ${ }^{\text {Se }}$ in water: $89 \%$ and $\mathrm{i}-\mathrm{PenM}^{\mathrm{Se}}$ in HBSS: $81 \% ; \mathrm{N}-\mathrm{PenM}^{\mathrm{Se}}$ in water: $92 \%$ and $\mathrm{N}-\mathrm{PenM}^{\mathrm{Se}}$ in HBSS: $86 \%$ 
to the $[\mathrm{M}+4 \mathrm{H}]^{4+}$ ion representing a mass of $2421.273 \mathrm{Da}(\Delta M \leq$ $1 \mathrm{ppm}$ ) which is $2.020 \mathrm{Da}$ less than that of $\mathrm{N}-\mathrm{PenM}^{\mathrm{Se}}$. A difference of $2.020 \mathrm{Da}$ might arise from loss of two hydrogen atoms (2.016 Da) due to cyclization or formation of a double bond.

Introduction of SeMet within the peptide sequence by exchange of Met was then pursued. By fully automated MW-assisted SPPS, SeMet was incorporated at the original position of Met into penetratin $\mathrm{i}-\mathrm{PenM}^{\mathrm{Se}}$, the sequence is shown in (Table 1). Purity of the synthesized peptide was determined by LC-ICP-MS to be $89 \%$. LC-ESI-MS revealed a signal at $m / z 1147.132$ corresponding to the $[\mathrm{M}+2 \mathrm{H}]^{2+}$ ion of the peptide, confirming the identity of i-PenM ${ }^{\text {Se }}(2292.250 \mathrm{Da})$ with a mass of $2292.248 \mathrm{Da}(\Delta M \leq 1 \mathrm{ppm})$ as the primary product. The $[\mathrm{M}+2 \mathrm{H}]^{2+}$ ion originating from the impurity was observed at $\mathrm{m} / \mathrm{z} 1155.131$ corresponding to a mass of 2308.246 Da ( $\Delta M \leq 1 \mathrm{ppm})$. The mass increase of $15.998 \mathrm{Da}$ indicated the presence of an additional oxygen atom (15.995 Da) that may arise from oxidation of the peptide, most likely in the SeMet residue. Oxidation of SeMet may have occurred during synthesis due to the exposure to oxygen at elevated temperatures in the synthesizer or during the purification process.

As only the oxidized impurity was identified for i-PenM ${ }^{\mathrm{Se}}$, mild synthesis conditions appear to be important in order to avoid oxidation of SeMet. Furthermore, a slightly higher peptide purity $(92 \%)$ was obtained for $\mathrm{N}-\mathrm{PenM}^{\mathrm{Se}}$ as compared to i-PenM $M^{\text {Se }}(89 \%)$. The purity of $\mathrm{i}-\mathrm{PenM}^{\text {Se }}$ might be improved in future by manual synthesis of the peptide or by using lower temperatures during coupling and deprotection steps. However, manual peptide synthesis is considerably more time-consuming, favoring automated synthesis. Improving the preparative HPLC method might also result in increased purity of the final product.

The stability of $\mathrm{i}$-PenM $\mathrm{M}^{\mathrm{Se}}$ in water was monitored by LC-ICP-MS during a two-month storage period. The ratio between the intact peptide and the impurity remained constant throughout the period (data not shown) confirming that the SeMet-labelled peptide was stable in aqueous solution. By dilution of the selenopeptides in HBSS medium, a decrease of the intact peptide was immediately observed in LC-ICP-MS chromatograms (Fig. 1). The mechanism behind this increased degradation is not clarified, but may be due to the higher ionic strength of the HBSS medium. The content of intact i-PenM ${ }^{\text {Se }}$ decreased from $89 \%$ to $81 \%$, while the content of intact N-PenM ${ }^{\text {Se }}$ decreased from $92 \%$ to $86 \%$. Only degradation to the formerly identified impurities was observed, thus no oxidation of $\mathrm{N}-\mathrm{PenM}^{\mathrm{Se}}$ was seen, whereas the presence of an oxidation product of $\mathrm{i}-\mathrm{PenM}^{\text {Se }}$ increased. This indicated that oxidation may be dependent on the position of SeMet in the peptide sequence.

The stability of fluorescently labelled penetratin has been investigated in a number of studies, as the translocation of the peptide and its function as a drug carrier may be dependent on the stability. Tréhin and colleagues have shown considerable degradation of carboxyfluorescein-labelled penetratin (CF-penetratin) in HBSS after 21 days of incubation, since only $76 \%$ of the intact peptide remained. ${ }^{10}$ In PBS supplemented with $1 \mathrm{~g} \mathrm{~L}^{-1}$ D-glucose, CF-penetratin was shown to be stable for only $1 \mathrm{~h} .{ }^{37}$ Thus, instability is also observed for the native Met-based penetratin.

\section{Cell uptake of selenopeptides}

Determination of total selenium by FI-ICP-MS. To test whether the synthesized selenium analogues of penetratin were able to penetrate the cell membrane, a two-hour uptake study in HeLa WT cells was conducted. Several studies have shown translocation of penetratin into eukaryotic cells with the HeLa WT cell line being one of the most frequently used cell lines. ${ }^{38}$

The total uptake of selenium from the peptides was determined by flow injection ICP-MS (FI-ICP-MS), (Table 2). SeMet was included as a positive control of the cell uptake experiment setup, as extensive cell uptake of SeMet has formerly been reported in e.g. the Caco-2 cell line. ${ }^{39}$ Considerable amounts of $\mathrm{i}-\mathrm{Pen} \mathrm{M}^{\mathrm{Se}}$ and $\mathrm{N}$-PenM ${ }^{\text {Se }}$ were taken up by the cells, $17.4 \pm 2.2 \mathrm{pmol}$ per $10^{4}$ cells of $\mathrm{i}-\mathrm{Pen} \mathrm{M}^{\mathrm{Se}}$ and $25.4 \pm 2.9 \mathrm{pmol}$ per $10^{4}$ cells of $\mathrm{N}-\mathrm{PenM} \mathrm{M}^{\mathrm{Se}}$, respectively. However, the selenium uptake from the peptides was not as pronounced as from SeMet, $49.6 \pm 3.3$ pmol per $10^{4}$ cells. Blank lysates contained no selenium.

The cellular uptake of penetratin has been studied by several groups in a variety of different human cell lines. The majority of these studies are based on fluorophore-labelled penetratin. Determination of CF-penetratin uptake in four different human carcinoma cell lines by total fluorescence spectrophotometry showed very different degrees of peptide internalization depending on the cell line. ${ }^{40,41}$ Lindgren and colleagues reported $14 \%$ uptake of total fluorescence of 2-aminobenzoic acid (Abz)-labelled penetratin in Caco-2 cells after $30 \mathrm{~min}$ incubation with $10 \mu \mathrm{M}$ peptide. ${ }^{34}$ Sarko et al. investigated the cellular uptake of ${ }^{111}$ In-DOTA-labelled penetratin in six different human carcinoma cell lines, where the uptake was determined using a $\gamma$-counter. Upon incubation for $30 \mathrm{~min}$ with cells, the amount of internalized radioactive label varied remarkably between different cell lines. ${ }^{25}$ As HeLa WT cells were not among the investigated cell lines, these data are not directly comparable to those obtained in the present work. Bahnsen et al. reported a semi-quantitative uptake of CF-labelled penetratin analogues in HeLa WT cells via determination by flowcytometry. ${ }^{32}$ However, the results were presented as relative to CF-penetratin uptake and they are thus not comparable to those of the present work.

Semi-quantitative determination of peptide uptake in HeLa WT cells by LC-ICP-MS. FI-ICP-MS revealed a similar uptake of selenium for $\mathrm{i}-\mathrm{Pen} \mathrm{M}^{\mathrm{Se}}$ and $\mathrm{N}-\mathrm{Pen} \mathrm{M}^{\mathrm{Se}}$. Speciation analysis of the lysates by reversed-phase (RP) LC-ICP-MS allowed estimation of whether penetratin was taken up by HeLa WT cells as the intact peptide or as degradation products. The amounts of peptide are

Table 2 Uptake in HeLa WT cells incubated for two hours with $10 \mu \mathrm{M}$ of i-PenM $M^{\text {Se }}, \mathrm{N}-$ PenM $^{\text {Se }}$ and SeMet. Total selenium in cell lysates was determined by $\mathrm{FI}-\mathrm{ICP}-\mathrm{MS}$, results obtained from one passage, three independent wells. Uptake of the intact peptide determined by LC-ICP-MS, results obtained from one lysate

\begin{tabular}{llll}
\hline & $\begin{array}{l}\text { Start Se } \\
\text { pmol per } 10^{4} \text { cells }\end{array}$ & $\begin{array}{l}\text { Total Se } \\
\text { pmol per } 10^{4} \text { cells }\end{array}$ & $\begin{array}{l}\text { Intact peptide } \\
\text { pmol per } 10^{4} \text { cells }\end{array}$ \\
\hline i-PenM $^{\text {Se }}$ & 505 & $17.4 \pm 2.2$ & 16.1 \\
N-PenM $^{\text {Se }}$ & 484 & $25.4 \pm 2.9$ & 18.4 \\
SeMet & 508 & $49.6 \pm 3.3$ & -
\end{tabular}


shown in Table 2. Hyphenation of RP gradient systems to ICP-MS is challenging, as the hot plasma in the ICP-MS will extinguish when exposed to high concentrations of organic solvent. This could be overcome by the use of narrow bore columns decreasing the flow rate considerably. However the use of high contents of $\mathrm{MeOH}$ may result in ICP-MS signal drift. ${ }^{24}$ In this study, the organic solvent from the mobile phase was removed by use of a membrane desolvation system. Chromatograms of cell lysates (Fig. 2) revealed that the main component passing the cell barrier in the case of both i-PenM $\mathrm{M}^{\mathrm{Se}}$ and $\mathrm{N}-\mathrm{Pen} \mathrm{M}^{\mathrm{Se}}$ was the intact peptide. This was confirmed by LC-ESI-MS ([M + $2 \mathrm{H}]^{2+} \mathrm{m} / z$ 1147.127, mass 2292.239, $\Delta M<5 \mathrm{ppm}$ and $[\mathrm{M}+3 \mathrm{H}]^{3+}$ $\mathrm{m} / \mathrm{z}$ 808.771, mass 2423.280, $\Delta M<5$ ppm, respectively). Thus 16.1 pmol per $10^{4}$ cells of $\mathrm{i}$-PenM $\mathrm{M}^{\mathrm{Se}}$ and 18.4 pmol per $10^{4}$ cells of $\mathrm{N}$-PenM ${ }^{\text {Se }}$ were observed in the respective HeLa WT cell lysates (Table 2). It is not possible from the present data to clarify if the minor amount of degradation products observed in the lysates entered the cells as such or were produced in the cells during uptake studies. Otherwise they may have been formed during the cell lysis upon adding a mixture of $0.1 \%$ triton $\mathrm{X}$ and $2 \%$ $\mathrm{CH}_{3} \mathrm{COOH}$. Very few studies have reported on speciation of cell lysates. Holm et al. investigated the intracellular degradation of CF-penetratin in yeast cells by RP-LC-fluorescence detection (FLD) after one hour of incubation. They showed that a high total uptake of the fluorophore was accompanied by extensive intracellular degradation of the peptide. ${ }^{11}$ A similar pattern was reported by Palm et al. for CF-penetratin uptake in non-mammalian cells
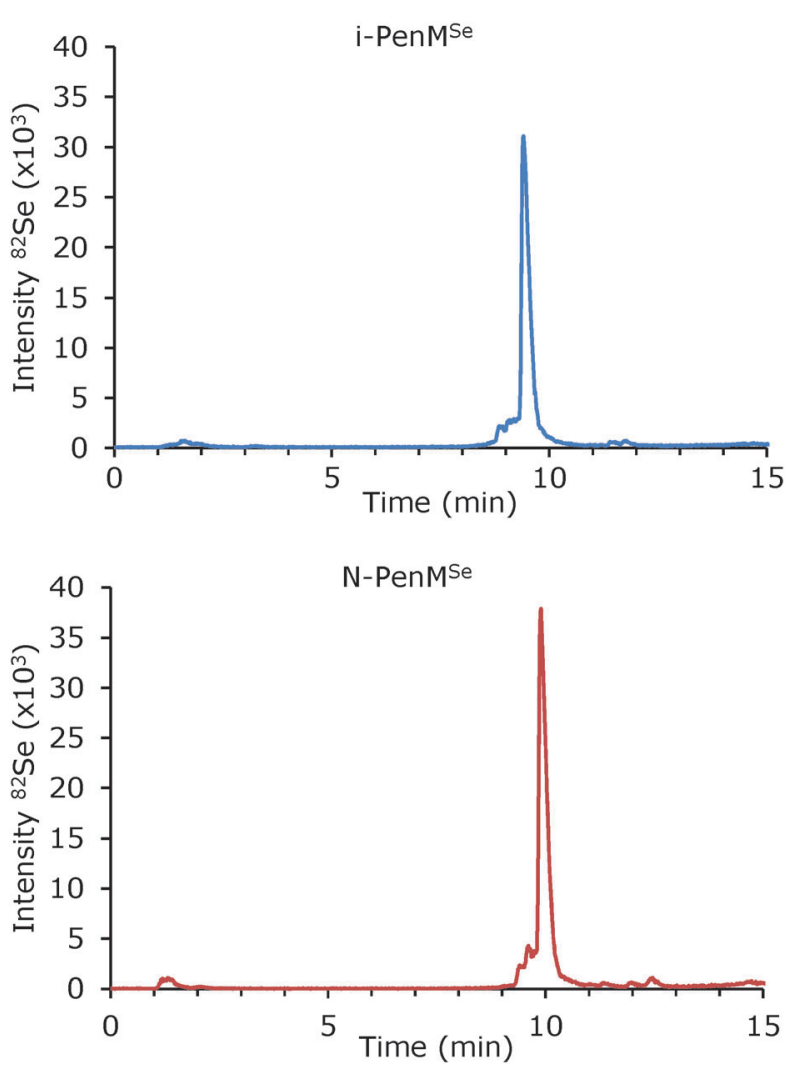

Fig. 2 LC-ICP-MS chromatograms of cell lysates from HeLa WT cells incubated with $10 \mu \mathrm{M}$ selenopeptide for $2 \mathrm{~h}$. upon incubation for one hour. ${ }^{42}$ These results are in contrast to the results of the present study. The percentage of intact peptides observed in HeLa WT cell lysates was $73 \%$ and $76 \%$ for $\mathrm{i}-\mathrm{PenM}^{\text {Se }}$ and $\mathrm{N}-\mathrm{PenM} \mathrm{M}^{\mathrm{Se}}$, respectively.

FI-ICP-MS and LC-ICP-MS of HeLa WT cell lysates demonstrated that cellular uptake of i-PenM ${ }^{\text {Se }}$ and N-PenM ${ }^{\text {Se }}$ mainly represented internalization of intact peptides. A direct comparison of these results to the existing literature was not possible, as different cell models and labels were applied.

Degradation of selenopeptides during cell uptake studies. Degradation of CF-penetratin has been reported to be a critical determinant for cellular uptake of penetratin. ${ }^{37}$ In order to fully exploit the drug delivery potential of penetratin, consistent evaluation of cellular uptake and stability is critical. Thus, degradation of the two synthetic selenopeptides, during incubation with HeLa WT cells in HBSS cell medium for two hours, was investigated. LC-ICP-MS analysis of samples from the HBSS medium revealed considerable additional degradation of the selenopeptides upon exposure to cells as compared to results obtained in cell-free HBSS. This is shown in Fig. 3. It appears that several new species appeared after exposure to cells in medium as compared to the cell-free medium in Fig. 1. The amount of the intact peptide present decreased for i-PenM ${ }^{\text {Se }}$ from $81 \%$ to $55 \%$, while for $\mathrm{N}-\mathrm{PenM} \mathrm{M}^{\mathrm{Se}}$ decreased from $86 \%$ to $61 \%$. The enhanced degradation during exposure to HeLa WT cells indicated that the degradation was primarily proteolytic rather than chemical. Proteolytic degradation of CF-penetratin when exposed to various cell lines has previously been correlated to cell line-dependent variations in stability. ${ }^{10,34}$

In order to investigate the mode of degradation further, the samples from the HBSS medium from uptake studies were analyzed by LC-ESI-MS. Degradation products of i-PenM ${ }^{\text {Se }}$ and $\mathrm{N}$-PenM $\mathrm{M}^{\text {Se }}$ were identified via their $\mathrm{m} / \mathrm{z}$ values, and sequences corresponding to these masses are suggested in Table 3 . The main compound observed for both i-PenM ${ }^{\text {Se }}$ and $\mathrm{N}-\mathrm{PenM}^{\mathrm{Se}}$ was the intact peptide (Fig. 3, peak a). Similar cleavage sites were observed for i-PenMSe and N-PenM ${ }^{\text {Se }}$ as illustrated in Fig. 4. Previous unpublished studies on penetratin stability by UPLCQTOF identified cleavage sites in native penetratin when exposed to human and rat gastrointestinal fluid that correspond to those observed for selenium-labelled penetratin analogues in the present study. ${ }^{43}$ Cleavage at the C-terminal site of arginine $(\mathrm{R})$ and lysine $(\mathrm{K})$ was confirmed to be caused by trypsin whereas cleavage at the C-terminal site of phenylalanine (F) was caused by chymotrypsin. ${ }^{43}$ Thus, the degradation products c, $\mathrm{d}$ and e shown in Fig. 3 may be due to the presence of trypsin while product $f$ may be a result of chymotrypsin. The composition of enzymes produced by HeLa cells is not reported, but some proteolytic activity is expected, which may include trypsin and chymotrypsin.

The degradation products identified from i-PenM ${ }^{\text {Se }}$ and $\mathrm{N}$-PenM $\mathrm{M}^{\mathrm{Se}}$ are listed in Table 3 and differed in the presence of selenium. In extracted ion chromatograms (EIC) of the LC-ESI-MS analysis, dissimilarities were at first observed by just a minor difference in the retention time of the peaks in the chromatograms (Fig. 3). Comparison to the LC-ICP-MS chromatograms revealed 

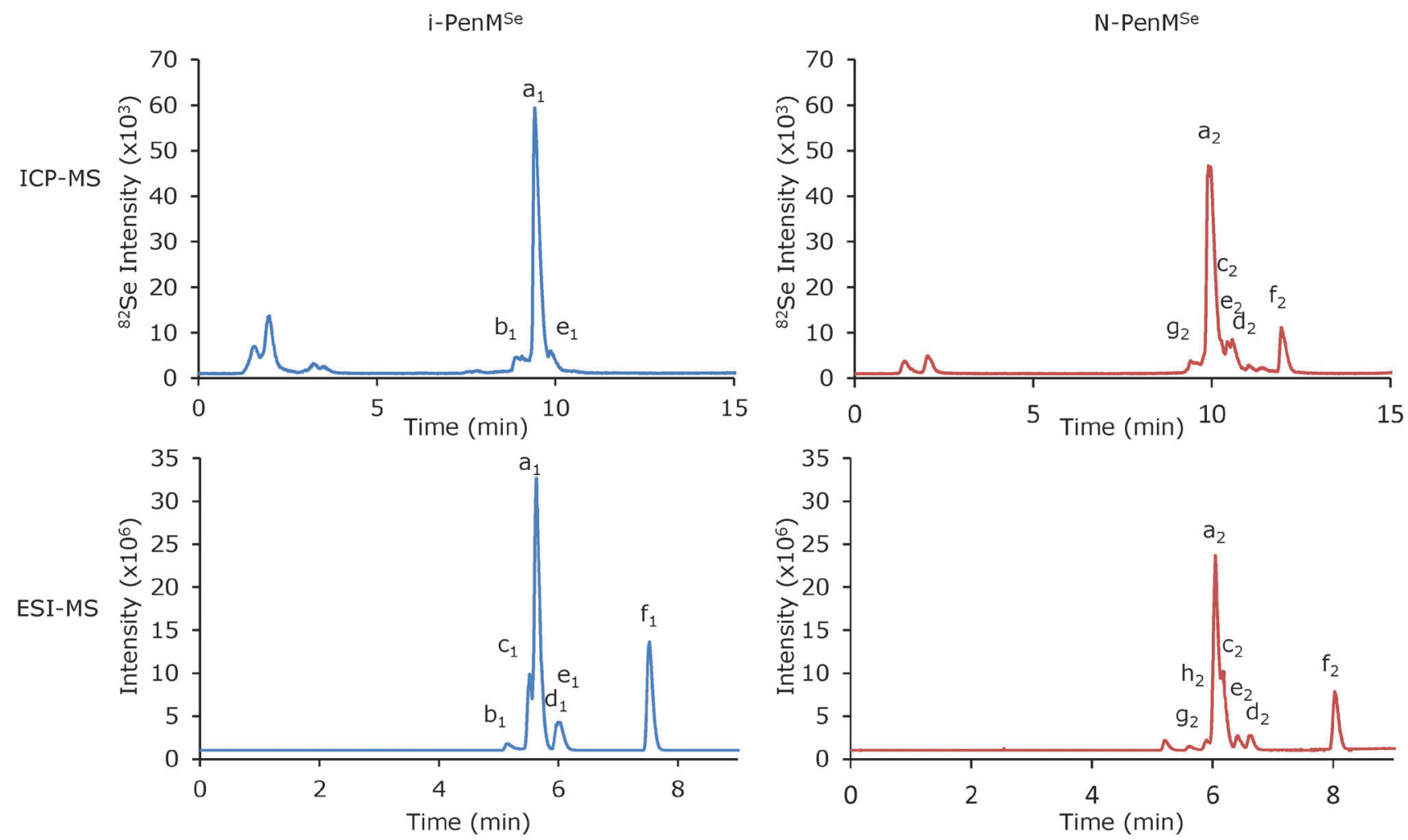

Fig. 3 Chromatograms of samples of Se-peptides in HBSS medium detected by ESI-MS and ICP-MS. MS chromatograms are extracted ion chromatograms (EIC) (i-PenM $M^{S e} \mathrm{~m} / z$ : $[\mathrm{M}+2 \mathrm{H}]^{2+}$ 495.798; $[\mathrm{M}+3 \mathrm{H}]^{3+} 515.637 ;[\mathrm{M}+2 \mathrm{H}]^{2+} 694.899 ;[\mathrm{M}+3 \mathrm{H}]^{3+} 722.721 ;[\mathrm{M}+3 \mathrm{H}]^{3+} 765.092 ;[\mathrm{M}+$ $3 H]^{3+}$ 770.425. N-PenM ${ }^{\text {Se }} \mathrm{m} / \mathrm{z}:[\mathrm{M}+3 \mathrm{H}]^{3+}$ 523.264; $[\mathrm{M}+3 \mathrm{H}]^{3+}$ 573.997; $[\mathrm{M}+3 \mathrm{H}]^{3+}$ 575.998; $[\mathrm{M}+2 \mathrm{H}]^{2+} 585.290 ;[\mathrm{M}+3 \mathrm{H}]^{3+} 697.409 ;[\mathrm{M}+3 \mathrm{H}]^{3+}$ 766.400; $[\mathrm{M}+3 \mathrm{H}]^{3+}$ 808.100; $[\mathrm{M}+3 \mathrm{H}]^{3+}$ 808.774). Annotation of the peaks corresponds to peptide sequences presented in Table 3.

Table 3 Sequences and masses of identified degradation products in medium samples from cell uptake experiments of i-PenM ${ }^{\text {Se }}$ and $\mathrm{N}$-PenM $\mathrm{Se}^{\mathrm{Se}}$ determined by LC-ESI-MS, mass accuracy $\leq 1 \mathrm{ppm}$. Sequences annotated in conformity to chromatograms are shown in Fig. 3

\begin{tabular}{|c|c|c|c|c|}
\hline & i-PenM $^{\text {Se }}(1)$ & $M_{\text {monoisotopic }}$ & $\mathrm{N}-\operatorname{PenM}^{\mathrm{Se}}(2)$ & $M_{\text {monoisotopic }}$ \\
\hline c & RQIKIWFQNRR-OH & 1543.885 & $\mathrm{M}^{\mathrm{Se}}$ RQIKIWFQNRR-OH & $\overline{1722.870}$ \\
\hline e & RQIKIWFQNRRM ${ }^{\mathrm{Se}} \mathrm{KWK}-\mathrm{OH}$ & 2165.139 & $\mathrm{M}^{\mathrm{Se}} \mathrm{RQIKIWFQNRRKWK-OH}$ & 2296.17 \\
\hline $\mathrm{f}$ & RQIKIWF-OH & 989.581 & $\mathrm{M}^{\text {Se}}$ RQIKIWF-OH & 1168.566 \\
\hline $\mathrm{g}$ & - & - & $\mathrm{N}-\mathrm{PenM}^{\mathrm{Se}}-2 \mathrm{Da}$ & 2421.275 \\
\hline
\end{tabular}

\section{h f d c e \\ i-PenMSe \\ RQIKIQWFQNRRMM ${ }^{\text {se }}$ KWKK-NH \\ N-PenMse $M^{\text {se }}$ R Q QIKIQWFQNRRMM KWKK- $\mathrm{NH}_{2}$}

Fig. 4 Cleavage sites of $\mathrm{i}$-PenMSe and $\mathrm{N}$-PenMSe after $2 \mathrm{~h}$ of incubation at $37{ }^{\circ} \mathrm{C}$ with HeLa WT-cells. Annotation corresponds to peaks in chromatograms in Fig. 3.

that the difference was due to the selenium labelling site. For instance, peak $\mathrm{f}$ was present in the LC-ICP-MS chromatogram of $\mathrm{N}-\mathrm{PenM}^{\mathrm{Se}}$ in medium, but not in that of $\mathrm{i}-\mathrm{PenM}^{\mathrm{Se}}$ in medium, whereas the peak appeared in both LC-ESI-MS EICs. Zooming in on the isotope patterns of the LC-ESI-MS peaks revealed a characteristic pattern for compounds containing selenium which was easily distinguished from a carbon pattern, exemplified for peak $\mathrm{f}$ in Fig. 5. The short peptide RQIKIWF from i-PenM ${ }^{\text {Se }}$ exhibited the common peptide carbon pattern $\left({ }^{12} \mathrm{C}, 98.90 \% ;{ }^{13} \mathrm{C}, 1.10 \%\right)$. The selenium-containing degradation product from $\mathrm{N}-\mathrm{PenM}^{\mathrm{Se}}, \mathrm{M}^{\mathrm{Se}} \mathrm{R}$ QIKIWF, displayed a combined pattern of carbon and selenium $\left({ }^{76} \mathrm{Se}, 9.0 \% ;{ }^{77} \mathrm{Se}, 7.6 \% ;{ }^{78} \mathrm{Se}, 23.6 \% ;{ }^{80} \mathrm{Se}, 49.7 \% ;{ }^{82} \mathrm{Se}, 9.2 \%\right)$. Hence, the characteristic isotope pattern of selenium demonstrates that selenium is also a useful molecular MS label.

Thus, differences between selenium-containing degradation products obtained from i-PenM ${ }^{\mathrm{Se}}$ and $\mathrm{N}-\mathrm{PenM} \mathrm{M}^{\mathrm{Se}}$, respectively, were revealed by LC-ICP-MS (chromatograms in Fig. 3) as only selenium-containing compounds were present. In general, 

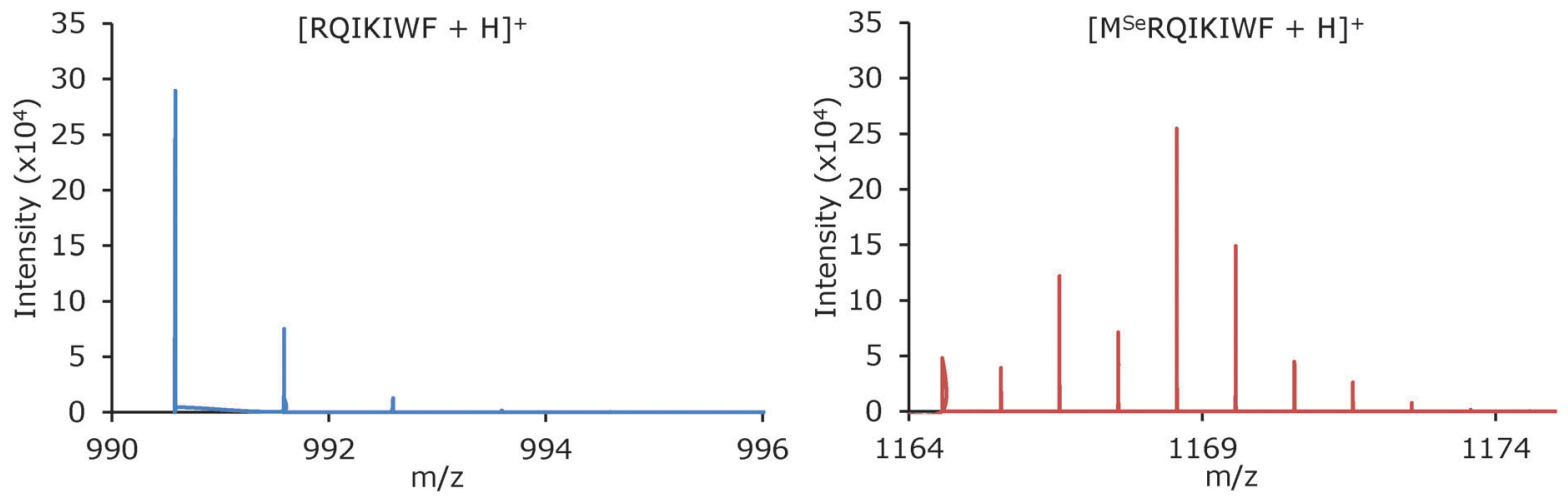

Fig. 5 Simulated isotope patterns of single charged peptides of [RQIKIWF $+H]^{+}$and $\left[M^{\text {Se }} \text { RQIKIWF }+H\right]^{+}$(peaks $f_{1}$ and $f_{2}$ in Fig. 3). Left: degradation product from $\mathrm{i}-\mathrm{PenM} \mathrm{M}^{\mathrm{Se}}$, isotope pattern without selenium. Right: degradation product of $\mathrm{N}-\mathrm{Pen} \mathrm{M}^{\mathrm{Se}}$ containing selenium.

amino acids and short polar peptides eluted in the beginning of the LC-ICP-MS chromatograms, while larger fragments and oxidation products appeared around the intact peptide. In N-PenM ${ }^{\mathrm{Se}}$, SeMet was added at the $\mathrm{N}$-terminal, and was thus retained in most of the cleaved peptides resulting in larger selenium-containing degradation products. By contrast, SeMet was incorporated towards the highly positively charged C-terminal in $\mathrm{i}-\mathrm{PenM}^{\mathrm{Se}}$, and therefore SeMet was predominantly cleaved off the parent peptide as very polar smaller Se-containing peptides eluting in the beginning of the chromatogram. Thus, the position of the label in the peptide sequence must be considered carefully in development and optimization of the LC methods. However, these results demonstrated that selenium labelling of penetratin indeed may be used as a readily detectable probe in evaluation of peptide degradation in various matrices by LC-ICP-MS and LC-ESI-MS. The possibility of specific detection of selenium offered by the ICP-MS technique implies that degradation in even more complex sample matrices may be analyzed.

\section{Analytical figures of merit}

Total selenium uptake in HeLa cells was successfully quantified by FI-ICP-MS while uptake of the intact peptide was semiquantitatively determined by LC-ICP-MS, exploiting the high selectivity and robustness of the ICP ionization. The limit of

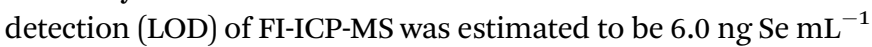
$\left(0.76 \mathrm{nmol}\right.$ Se injected) as $3 \sigma$ of the peak area of $2.4 \mu \mathrm{M} \mathrm{i-PenM^{ \textrm {Se } }}$. FI-ICP-MS precision of three repeated injections of $2.4 \mu \mathrm{M}$ i-PenM ${ }^{\text {Se }}$ was $1.0 \%$ relative standard deviation (RSD). The LOD for the LC-ICP-MS method was $6.5 \mathrm{ng} \mathrm{Se} \mathrm{mL}{ }^{-1}(0.41 \mathrm{nmol} \mathrm{Se}$ on column) estimated as $3 \sigma$ of the peak area of $2.4 \mu \mathrm{M}$ i-PenM ${ }^{\mathrm{Se}}$. The column recovery was $101.5 \pm 1.1 \%(n=3)$ and $101.9 \pm 0.3 \%$ $(n=2)$ for $\mathrm{i}-\mathrm{PenM}^{\mathrm{Se}}$ and $\mathrm{N}-\mathrm{Pen} \mathrm{M}^{\mathrm{Se}}$ respectively. The precision of three repeated injections of $2.4 \mu \mathrm{M}$ i-PenM ${ }^{\mathrm{Se}}$ was $1.3 \% \mathrm{RSD}$.

The LOD for the FI-ICP-MS method in this study was higher than what has previously been reported for low molecular selenium compounds. ${ }^{39}$ Peptides are known to exhibit unspecific adsorption onto different materials, e.g. glass, metal and plastic. ${ }^{7}$ Adsorption onto vials, injection needle or tubing might explain the increased LOD. The flow injection method was thoroughly optimized to avoid unspecific adsorption by acidification and the increase of the peptide concentration in samples. However, adsorption might still contribute to increased deviation between injections, resulting in a higher LOD for peptides as compared to smaller selenium compounds. Furthermore, the low-abundant selenium isotope ${ }^{82} \mathrm{Se}(9.2 \%)$ was measured in the present work, due to the polyatomic interference of ${ }^{40} \mathrm{Ar}_{2}$ of the most abundant isotope ${ }^{80} \mathrm{Se}(49.7 \%)$ using the ELAN 6000 quadrupole instrument. Sufficient sensitivity was achieved by ELAN 6000 for the measurements of the present study. However, detection limits may be reduced by application of improved ICP-MS instrumentation, e.g. by applying a dynamic reaction cell (DRC) instrument. ${ }^{44}$

\section{Conclusion}

In this study, selenium incorporated as SeMet was demonstrated to be a useful label for quantification of pharmaceutically relevant peptides exemplified by the cell-penetrating peptide, penetratin. Selenium was readily introduced during solid-phase peptide synthesis, however, the stability of SeMet at higher temperatures must be considered. The introduction of the non-toxic SeMet label is considered to have a minimal effect on the biological activity of the peptide. Selenium labelling thus offers minimal disturbance of the native structure of the peptide of interest as compared to labelling with fluorophores or metal-chelating agents. The labelling technique and a combination of FI-ICP-MS, LC-ICP-MS and LC-ESI-MS techniques provided detailed information on the fate of penetratin in cell uptake studies. In addition to qualitative information on degradation products obtainable from LC-ESI-MS, LC-ICP-MS allowed for quantification of the peptide. Most therapeutic peptides are synthetic analogues of endogenous peptides, and incorporation of selenium allows for improved critical assessment of the native drug or drug delivery candidate early in the drug development process.

\section{References}

1 D. J. Craik, D. P. Fairlie, S. Liras and D. Price, Chem. Biol. Drug Des., 2013, 81, 136-147. 
2 A. A. Kaspar and J. M. Reichert, Drug Discovery Today, 2013, 18, 807-817.

3 P. Vlieghe, V. Lisowski, J. Martinez and M. Khrestchatisky, Drug Discovery Today, 2010, 15, 40-56.

4 M. Grant and A. Leone-Bay, Ther. Delivery, 2012, 3, 981-996.

5 e. Khafagy and M. Morishita, Adv. Drug Delivery Rev., 2012, 64, 531-539.

6 T. Bruckdorfer, O. Marder and F. Albericio, Curr. Pharm. Biotechnol., 2004, 5, 29-43.

7 H. Grohganz, M. Rischer and M. Brandl, Eur. J. Pharm. Sci., 2004, 21, 191-196.

8 D. Farin, G. A. Piva, I. Gozlan and R. Kitzes-Cohen, J. Pharm. Biomed. Anal., 1998, 18, 367-372.

9 D. W. Backes, H. I. Aboleneen and J. A. Simpson, J. Pharm. Biomed. Anal., 1998, 16, 1281-1287.

10 R. Tréhin, H. M. Nielsen, H. G. Jahnke, U. Krauss, A. G. Beck-Sickinger and H. P. Merkle, Biochem. J., 2004, 382, 945-956.

11 T. Holm, S. Netzereab, M. Hansen, U. Langel and M. Hallbrink, FEBS Lett., 2005, 579, 5217-5222.

12 I. van den Broek, R. W. Sparidans, J. H. Schellens and J. H. Beijnen, J. Chromatogr. B: Anal. Technol. Biomed. Life Sci., 2008, 872, 1-22.

13 A. Prange and D. Pröfrock, J. Anal. At. Spectrom., 2008, 23, 432-459.

14 E. Svantesson, J. Pettersson and K. E. Markides, J. Anal. At. Spectrom., 2002, 17, 491-496.

15 D. Kretschy, G. Koellensperger and S. Hann, Anal. Chim. Acta, 2012, 750, 98-110.

16 M. Wang, W. Y. Feng, Y. L. Zhao and Z. F. Chai, Mass Spectrom. Rev., 2010, 29, 326-348.

17 A. Sanz-Medel, M. Montes-Bayon, M. del Rosario Fernandez de la Campa, J. R. Encinar and J. Bettmer, Anal. Bioanal. Chem., 2008, 390, 3-16.

18 S. Bomke, M. Sperling and U. Karst, Anal. Bioanal. Chem., 2010, 397, 3483-3494.

19 Y. He, Y. Zhang, C. Wei, C. Li, Y. Gao and R. Liu, Appl. Spectrosc. Rev., 2013, 49, 492-512.

20 R. Liu, X. Hou, Y. Lv, M. McCooeye, L. Yang and Z. Mester, Anal. Chem., 2013, 85, 4087-4093.

21 M. W. Yang, Z. W. Wang, L. Fang, J. P. Zheng, L. J. Xu and F. F. Fu, J. Anal. At. Spectrom., 2012, 27, 946-951.

22 G. Schwarz, S. Beck, M. G. Weller and M. W. Linscheid, Anal. Bioanal. Chem., 2011, 401, 1203-1209.
23 D. Esteban-Fernandez, C. Scheler and M. W. Linscheid, Anal. Bioanal. Chem., 2011, 401, 657-666.

24 G. Koellensperger, M. Groeger, D. Zinkl, P. Petzelbauer and S. Hann, J. Anal. At. Spectrom., 2009, 24, 97-102.

25 D. Sarko, B. Beijer, B. R. Garcia, E. M. Nothelfer, K. Leotta, M. Eisenhut, A. Altmann, U. Haberkorn and W. Mier, Mol. Pharmaceutics, 2010, 7, 2224-2231.

26 L. A. Wessjohann, A. Schneider, M. Abbas and W. Brandt, Biol. Chem., 2007, 388, 997-1006.

27 P. Whanger, J. Am. Coll. Toxicol., 1986, 5, 101-110.

28 M. Muttenthaler and P. F. Alewood, J. Pept. Sci., 2008, 14, 1223-1239.

29 S. Lang, D. E. Spratt, J. G. Guillemette and M. Palmer, Anal. Biochem., 2005, 342, 271-279.

30 D. Derossi, A. H. Joliot, G. Chassaing and A. Prochiantz, J. Biol. Chem., 1994, 269, 10444-10450.

31 C. Foged and H. M. Nielsen, Expert Opin. Drug Delivery, 2008, 5, 105-117.

32 J. S. Bahnsen, H. Franzyk, A. Sandberg-Schaal and H. M. Nielsen, Biochim. Biophys. Acta, 2013, 1828, 223-232.

33 P. M. Fischer, N. Z. Zhelev, S. Wang, J. E. Melville, R. Fahraeus and D. P. Lane, J. Pept. Res., 2000, 55, 163-172.

34 M. E. Lindgren, M. M. Hallbrink, A. M. Elmquist and U. Langel, Biochem. J., 2004, 377, 69-76.

35 P. E. Thoren, D. Persson, P. Isakson, M. Goksor, A. Onfelt and B. Norden, Biochem. Biophys. Res. Commun., 2003, 307, 100-107.

36 R. Tréhin, U. Krauss, A. G. Beck-Sickinger, H. P. Merkle and H. M. Nielsen, Pharm. Res., 2004, 21, 1248-1256.

37 C. Palm, M. Jayamanne, M. Kjellander and M. Hallbrink, Biochim. Biophys. Acta, 2007, 1768, 1769-1776.

38 M. Zorko and U. Langel, Adv. Drug Delivery Rev., 2005, 57, 529-545.

39 B. Gammelgaard, L. H. Rasmussen, C. Gabel-Jensen and B. Steffansen, Biol. Trace Elem. Res., 2012, 145, 248-256.

40 A. Elmquist, M. Lindgren, T. Bartfai and U. Langel, Exp. Cell Res., 2001, 269, 237-244.

41 P. Lundberg and Ü. Langel, Int. J. Pept. Res. Ther., 2006, 12, 105-114.

42 C. Palm, S. Netzerea and M. Hallbrink, Peptides, 2006, 27, 1710-1716.

43 M. V. Christensen, Master thesis, University of Copenhagen, 2012.

44 S. D. Tanner, V. I. Baranov and U. Vollkopf, J. Anal. At. Spectrom., 2000, 15, 1261-1269. 